\title{
Akuntabilitas dan Transparansi Pengelolaan Alokasi Dana Desa di Desa Sumber Rejeki Kecamatan Pulau Rimau Kabupaten Banyuasin
}

\author{
Tri Nurjanah ${ }^{1}$, Jusmani ${ }^{2}$, Totok Sudiyanto ${ }^{3}$ \\ ${ }^{1}$ Fakultas Ekonomi Universitas PGRI Palembang, trinurianah12@gmail.com \\ ${ }^{2}$ Fakultas Ekonomi Universitas PGRI Palembang, jusmani@univpgri-palembang.ac.id \\ ${ }^{3}$ Fakultas Ekonomi Universitas PGRI Palembang, totoktajir1978@gmaiil.com
}

\begin{abstract}
This study aims to measure the Accountability and Transparency of Village Fund Allocation Management (ADD) in Sumber Rejeki Village per year, to find out what obstacles are experienced in the Management of Village Fund Allocation in Sumber Rejeki Village, in addition to that the researcher also wants to know what impacts if not There is accountability and transparency in the Management of Village Fund Allocation in Sumber Rejeki Village. This research was conducted using a qualitative descriptive method and data was collected through documentation, such as the village government work planner program archives, evidence of ADD funds disbursement, evidence of receipts and expenditures from the treasurer, accountability reports, description results obtained through measurement by comparing the law of the Minister of Home Affairs. number 113 of 2014 with actual field activities. The results showed that research based on Permendagri Number 113 of 2014 shows that in general the management of the Sumber Rejeki village fund allocation is transparent and accountable at the planning, reporting, and accountability stages. In realizing transparency in the Management of Village Fund Allocation by Desa Sumber Rejeki, the village provides information to the community through village deliberations containing information on Village Fund Allocation for each program design implemented to support Sumber Rejeki village activities.
\end{abstract}

Keywords: Village Fund Allocation, Accountability, Transparency

\begin{abstract}
ABSTRAK
Penelitian ini bertujuan untuk mengukur Akuntabilitas dan Transparansi Pengelolaan Alokasi Dana Desa (ADD) di Desa Sumber Rejeki per tahunnya, untuk mengetahui kendala apa saja yang dialami dalam Pengelolaan Alokasi Dana Desa di Desa Sumber Rejeki, selain itu juga peneliti ingin mengetahui dampak apa saja jika tidak ada akuntabilitas dan transparansi Pengelolaan Alokasi Dana Desa di Desa Sumber Rejeki. Penelitian ini dilakukan dengan menggunakan metode deskriptif kualitatif dan data dikumpulkan melalui dokumentasi, seperti arsip program perencana kerja pemerintah desa, bukti pencairan dana ADD, bukti penerima dan pengeluaran dari bendahara, laporan pertanggungjawaban, hasil deskripsi yang di dapat melalui pengukuran dengan membandingkan undang-undang permendagri nomor 113 tahun 2014 dengan kegiatan lapangan sesungguhnya. Hasil penelitian menunjukkan bahwa penelitian berdasarkan Permendagri Nomor 113 tahun 2014 menunjukkan secara garis besar pengelolaan alokasi dana desa Sumber Rejeki sudah transparan dan akuntabel pada tahapan perencanaan, pelaporan, dan pertaggungjawabannya. Dalam mewujudkan transparansi Pengelolaan Alokasi Dana Desa oleh pihak Desa Sumber Rejeki memberikan informasi kepada masyarakat melalui musyawarah desa yang memuat informasi Alokasi Dana Desa untuk setiap rancangan program yang dilaksanakan untuk mendukung aktifitas desa Sumber Rejeki.
\end{abstract}

Kata Kunci: Alokasi Dana Desa, Akuntabilitas, Transparansi

\section{A. PENDAHULUAN}

Undang-Undang Nomor. 6 Tentang Desa 2014, desa merupakan sebuah kesatuan masyarakat hukum yang memiliki batas-batas wilayah yang berwenang untuk mengatur dan mengurus kepentingan masyarakat setempat, berdasarkan asalusul dan adat istiadat setempat yang diakui dan di hormati dalam sistem pemerintahan Negara Republik Indonesia. Untuk mengatur dan mengurus 
kepentingan masyarakat yang bertempat tinggal di desa diperlukan pendapatan desa agar tujuan pembangunan desa dapat tercapai, salah satu bentuk pendapatan dari pemerintah untuk menunjang pembangunan di desa adalah Alokasi Dana Desa (ADD).

Pemerintah mengalokasikan dana desa dalam anggaran pendapatan dan belanja negara (APBN) yang diperuntukan bagi desa yang ditransfer melalui anggaran pendapatan dan belanja daerah (APBD) Kabupaten/Kota untuk pembangunan desa, yaitu dalam bentuk Alokasi Dana Desa (ADD). Dalam UndangUndang tersebut menjelaskan bahwa desa akan mendapatkan dana sebesar paling sedikit $10 \%$ dari dana perimbangan yang diterima Kabupaten/Kota dalam APBD setelah dikurangi alokasi dana khusus.

Pengelolaan dan perencanaan kegiatan pemerintah desa, perlu adanya suatu aspek tata pemerintah yang baik. Salah satu unsur utama dari pemerintah yang baik adalah akuntabilitas. Akuntabilitas adalah bentuk tanggungjawab pelaksanaan dan misi organisasi dalam mencapai tujuan yang telah ditetapkan melalui pertanggungjawaban yang dilaksanakan secara periodik.

Selain akuntabilitas untuk pelaksanaan pemerintah yang baik juga diperlukan adanya unsur transparansi. Transparansi dan akuntabilitas adalah dua kata kunci dalam penyelenggaran pemerintah maupun penyelenggara pemerintah yang baik. Transparansi ditandai oleh kebijakan, regulasi, program, anggaran, dan kegiatan pemerintah terbuka pada publik.

Desa Sumber Rejeki merupakan salah satu desa yang terletak di Kecamatan Pulau Rimau Kabupaten Banyuasin. Mayoritas penduduk desa Sumber Rejeki sebagai buruh petani. Di dasarkan pada realita bahwa sebagai pilar otonomi daerah, desa semakin membutuhkan pendanaan yang seimbang untuk menjalankan peran yang lebih dalam pembangunan daerah.

Permasalahan pada tahap perencanaan penggunaan alokasi dana desa yaitu kurangnya keterbukaan kepada masyarakat pada saat musyawarah dalam pembahasan rencana penggunaan Alokasi Dana Desa (ADD) yang hanya dihadiri oleh orang-orang tertentu saja, sementara hasil dari pembahasan perencanaan secara transparansi penggunaan Alokasi Dana Desa (ADD) tidak diinformasikan kepada masyarakat secara umum sehingga masyarakat tidak tahu bahwa desa mendapatkan bantuan dana yang besar dari pemerintah daerah.

\section{B. KAJIAN TEORI}

\section{Desa dan Pemerintah Desa}

Sujarweni (2015:1) Desa adalah kesatuan wilayah yang dihuni oleh sejumlah keluarga yang mempunyai sistem pemerintahan sendiri (dikepalai oleh seorang kepala desa) atau desa merupakan kelompok rumah diluar kota yang merupakan kesatuan.

Permendagri No 113 Tahun 2014 Pemerintah Desa adalah penyelenggara urusan pemerintahan dan kepentingan masyarakat setempat dalam sistem pemerintahan Negara Kesatuan Republik Indonesia. Pemerintah Desa adalah kepada desa atau yang disebut dengan nama lain dibantu perangkat desa sebagai unsur penyelenggara pemerintah desa.

\section{Akuntansi Untuk Akuntabilitas Publik}

Mahmudi (2011:18) Akuntabilitas publik adalah kewajiban pemegang amanah (agent) untuk memberikan pertanggungjawaban, menyajikan, melaporkan, dan mengungkapkan segala aktivitas dan kegiatan yang menjadi tanggungjawabnya 
kepada pihak pemberi amanah (principal) yang memiliki hak dan kewenangan untuk meminta pertanggungjawaban tersebut.

Akuntabilitas publik yang harus dilakukan oleh organisasi sktor publik terdiri atas beberapa aspek yaitu sebagai berikut:

a. Akuntabilitas Hukum dan Kejujuran

b. Akuntabilitas Manajerial

c. Akuntabilitas Program

d. Akuntabilitas Kebijakan

e. Akuntabilitas Finansial

\section{Akuntansi Untuk Transparansi}

Mahmudi (2011:17:18) Transparansi memiliki arti keterbukaan organisasi dalam memberikan informasi yang terkait dengan aktivitas pengelolaan sumber daya publik kepada pihak-pihak yang menjadi pemaku kepentingan. Transparansi juga berarti adanya penjelasan manajemen organisasi sektor publik tentang aktivitas, program dan kebijakan yang sudah dilakukan beserta sumber daya yang digunakannya.

Dengan dilakukannya transparansi tersebut publik akan memperoleh informasi yang aktual dan faktual, sehingga mereka dapat menggunakan informasi tersebut (Mahmudi 2011:18):

a. Membandingkan kinerja keuangan yang dicapai dengan yang direncanakan (realisasi dan anggaran)

b. Menilai ada tidaknya unsur korupsi dan manipulasi dalam perencanaan, pelaksanaan, dan pertanggungjawaban anggaran

c. Menentukan tingkat kepatuhan terhadap peraturan perundangan yang terkait

d. Mengetahui hak dan kewajiban masing-masing pihak, yaitu antara manajemen organisasi sektor publik dengan masyarakat dan dengan pihak lain yang terkait.

\section{Asas-Asas Pengelolaan Keuangan Desa}

Setyadi (2019:104) asas pengelolaan keuangan desa merupakan nilai-nilai yang menjiwai pengelolaan keuangan desa, asas dimaksud melahirkan prinsipprinsip dasar dan menjadi cerminan dalam setiap tindakan pengelolaan keuangan desa. Dana desa sebagai salah satu sumber pendapatan desa, pengelolaannya dilakukan dalam kerangka pengelolaan keuangan desa.

\section{Alokasi Dana Desa}

Peraturan Pemerintah (PP) Nomor 60 Tahun 2014 Setyadi (2019:25) tentang dana desa yang bersumber dari anggaran pendapatan dan belanja negara adalah dana yang bersumber dari anggaran pendapatan dan belanja negara yang diperuntukkan bagi desa yang ditransfer melalui anggaran pendapatan dan belanja daerah Kabupaten/Kota dan digunakan untuk membiayai penyelenggaraan pemerintahan, pelaksanaan pembangunan, pembinaan kemasyarakatan, dan pemberdayaan masyarakat.

Peraturan Bupati No 12 Tahun 2015 tentang pedoman umum pelaksana alokasi dana desa pada pasal 4 bahwa dana alokasi dana desa berasal dari dana perimbangan keuangan pusat dan daerah yang diterima oleh kabupaten sebesar $10 \%$ yang bersumber dari bagi hasil pajak dan sumber daya alam dana alokasi umum dikurangi belanja pegawai.

\section{Pengelolaan Keuangan Desa}

Permendagri No 113 Tahun 2014 pengelolaan keuangan desa adalah keseluruhan kegiatan yang meliputi: 

1. Perencanaan
2. Pelaksanaan
3. Penatausahaan
4. Pelaporan
5. Pertanggungjawaban

\section{Sasaran dan Tujuan Dana Desa}

Setyadi (2019:26) Sasaran yang ingin dicapai melalui pengalokasian dana desa ini adalah sebagai berikut:

a. Dana desa digunakan untuk membiayai penyelenggaraan pemerintah, pembangunan, pemberdayaan masyarakat, dan kemasyarakatan.

b. Dana desa diprioritaskan untuk pembangunan dan pemberdayaan masyarakat.

Setyadi (2019:26) tujuan dana desa disalurkan secara umum kepada masyarakat antara lain sebagai berikut:

a. Meningkatkan pelayanan publik di desa

b. Mengataskan kemiskinan

c. Memajukan perekonomian masyarakat

d. Mengatasi kesenjangan pembangunan antar desa

e. Memperkuat masyarakat desa sebagai subjek dari pembangunan.

\section{Sumber Pendapatan Desa}

Berdasarkan Undang-Undang Nomor 6 Tahun 2014 tentang Desa Pasal 72 Ayat (1), pendapatan desa bersumber dari:

1. Pendapatan Asli Desa

2. Dana Desa dari APBN

3. Bagian dari hasil pajak daerah dan retribusi daerah kabupaten/kota (paling sedikit $10 \%$ dari dana bagi hasil dan dana alokasi umum).

4. Bantuan keuangan dari APBD Provinsi dan APBD Kabupaten/Kota.

5. Hibah dan sumbangan dari pihak ketiga

6. Lain-lain pendapatan desa yang sah.

\section{Kerangka Pemikiran}

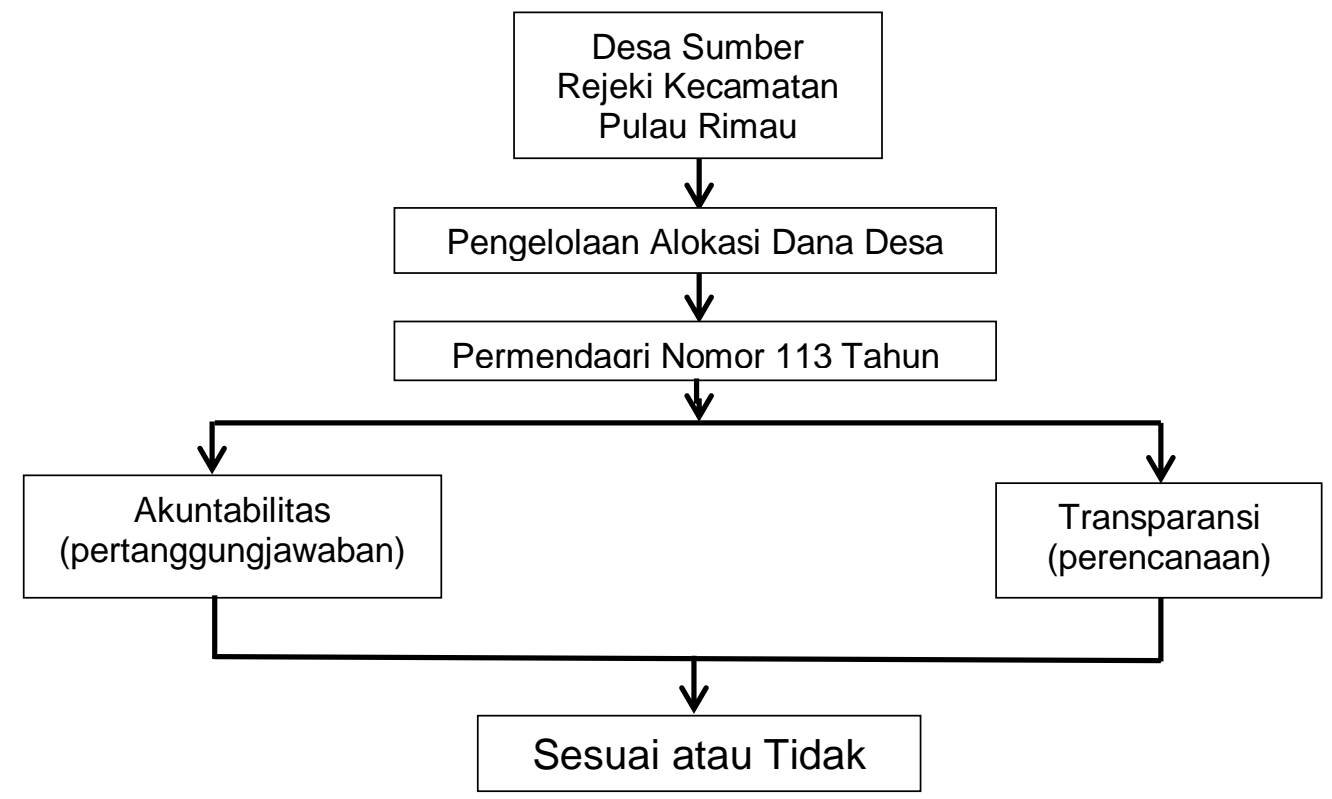

Gambar Kerangka Pemikiran 
Berdasarkan kerangka berpikir diatas dijelaskan bahwa dana desa yang diberikan oleh pemerintah desa kepada desa sumber rejeki. Dana desa yang diberikan pemerintah adalah untuk kemajuan desa yang diolah oleh kepala desa yang berdasarkan Permendagri nomor 113 Tahun 2014. Dari pengelolaan alokasi dana desa akan dilihat apakah penerapan akuntabilitas dan transparansi pengelolaan aloksi dana desa sudah sesuai atau belum dengan Permendagri Nomor 113 Tahun 2014.

\section{METODE PENELITIAN}

Sugiyono (2018:2) metode penelitian diartikan sebagai cara ilmiah untuk mendapatkan data dengan tujuan dan kegunaan tertentu.

Metode penelitian yang digunakan dalam penelitian ini adalah metode kualitatif dengan menguraikan teori-teori yang relevan terhadap laporan pertanggungjawaban untuk mengetahui bagaimana mengumpulkan data yang berkaitan dengan alokasi dana desa di Desa Sumber Rejeki Kecamatan Pulau Rimau.

\section{Variabel Penelitian}

Noor (2015:47) variabel penelitian merupakan kegiatan menguji hipotesis, yaitu menguji kecocokan antara teori dan fakta empiris di dunia nyata.

Variabel yang digunakan dalam penelitian adalah perencanaan, pelaporan dan pertanggungjawaban.

\section{Definisi Operasional Variabel}

Sujarweni (2019:77) definisi oprasional merupakan variabel penelitian yang dimaksudkan untuk memahami arti setiap variabel penelitian sebelum dilakukan analisis, instrumen dan sumber pengukuran berasal darimana.

TABEL DEFINISI OPERASIONAL VARIABEL

\begin{tabular}{|c|c|c|}
\hline Variabel & Definisi & Indikator \\
\hline Akuntabilitas & $\begin{array}{l}\text { Akuntabilitas merupakan kewajiban pemegang } \\
\text { amanah (agent) untuk } \\
\text { pertanggungjawaban, menyajikan, melaporkan, } \\
\text { dan mengungkapkan segala aktivitas dan kegiatan } \\
\text { yang menjadi tanggungjawabnya kepada pihak } \\
\text { pemberi amanah (principal) yang memiliki hak dan } \\
\text { kewenangan untuk meminta pertanggungjawaban } \\
\text { tersebut. Mahmudi (2011:18) }\end{array}$ & $\begin{array}{ll}- & \text { Perencanaan } \\
\text { - } & \text { Pelaporan } \\
- & \text { pertanggungjawaban }\end{array}$ \\
\hline Transparasi & $\begin{array}{l}\text { Transparan merupakan keterbukaan organisasi } \\
\text { dalam memberikan informasi yang terkait dengan } \\
\text { aktivitas pengelolaan sumber daya publik kepada } \\
\text { pihak-pihak yang menjadi pemaku kepentingan. } \\
\text { Mahmudi (2011:17) }\end{array}$ & Laporan realisasi APBD \\
\hline
\end{tabular}

\section{Populasi dan Sampel}

\section{Populasi}

Noor (2015:147) populasi adalah seluruh elemen dari suatu wilayah yang menjadi sasaran penelitian atau objek penelitian. Populasi dalam penelitian ini adalah Alokasi Dana Desa.

\section{Sampel}

Hermawan (2017:96) sampel merupakan suatu bagian dari populasi. Hal ini mencakup sejumlah anggota yang dipilih dari populasi. 
Sampel dalam penelitian ini adalah Akuntabilitas dan Transparansi Alokasi Dana Desa di Desa Sumber Rejeki Kecamatan Pulau Rimau Kabupaten Banyuasin.

\section{Sumber Data}

Sugiyono (2018:219) dilihat dari sumber datanya ada dua jenis sumber data yang dapat digunakan oleh pengumpulan data yaitu:

\section{Data Primer}

Data Primer adalah sumber data yang langsung memberikan data pada pengumpul data.

\section{Data Sekunder}

Sumber Sekunder merupakan sumber yang tidak langsung memberikan data kepada pengumpul data.

Sumber data dalam penelitian ini adalah data sekunder berupa bukti pencairan dana ADD di Desa Sumber Rejeki Kecamatan Pulau Rimau Kabupaten Banyuasin.

\section{Teknik Pengumpulan Data}

Noor (2015:138) teknik pengumpulan data merupakan cara mengumpulkan data yang dibutuhkan untuk menjawab rumusan masalah penelitian.

Sugiono (2018:240) Dokumentasi merupakan catatan peristiwa yang berlalu berbentuk gambar, foto, sketsa dan lain-lain.

Adapun teknik pengumpulan data yang di gunakan dalam penelitian ini adalah dokumentasi, seperti arsip program perencana kerja pemerintah desa, bukti pencairan dana ADD, bukti penerima dan pengeluaran dari bendahara, laporan pertanggungjawaban.

\section{Teknik Analisis Data}

Sujarweni (2019:121) teknis analisis data merupakan cara melaksanakan analisis terhadap data dengan tujuan mengelola data tersebut untuk menjawab rumusan masalah.

Teknik analisis yang digunakan dalam penelitian ini adalah deskriptif kualitatif, deskriptif kualitatif adalah hasil yang didapat melalui pengukuran dengan membandingkan Undang-Undang Permendagri Nomor 113 Tahun 2014 dengan kegiatan lapangan sesungguhnya.

\section{HASIL PENELITIAN}

1. Perencanaan Alokasi Dana Desa (ADD) di Desa Sumber Rejeki Kecamatan Pulau Rimau Kabupaten Banyuasin

Perencanaan keuangan desa Sumber Rejeki secara teknis harus berpedoman pada Permendagri No. 113 Tahun 2014 tentang pengelolaan keuangan desa. Berdasaran Permendagri No. 113 Tahun 2014 Pasal 14 bahwa sekertaris desa menyusun rancangan peraturan desa tentang APBD berdasarkan rekap desa. Kemudian sekertaris desa menyampaikan kepada kepala desa dan kepada BPD untuk disepakati lebih lanjut. Terkait fungsi BPD adalah membahas dan menyepakati rancangan peraturan desa bersama kepala desa, BPD juga memiliki hak dan kewajiban untuk menyetujui dan menolak rancangan peraturan desa yang diajukan kepada kepala desa.

\section{Perencanaan Transparansi Alokasi Dana Desa (ADD) di Desa Sumber Rejeki Kecamatan Pulau Rimau Kabupaten Banyuasin}

Perencanaan transparansi pengelolaan keuangan desa sudah berjalan dengan baik. Hal ini dibuktikan dengan adanya masyarakat yang antusias menghadiri forum 
musyawarah desa. Musyawarah tersebut dilakukan oleh kepala desa yang bertujuan untuk membahas mengenai program kerja seperti pembangunan jalan, pembuatan sumur bor, dan pembangunan mushola. Dengan demikian masyarakat mengetahui pengeluaran dana yang dibutuhkan dalam pelaksanaan program kerja tersebut.

\section{Pelaporan/Pertanggungjawaban Alokasi Dana Desa (ADD) di Desa Sumber Rejeki Kecamatan Pulau Rimau}

Akuntabilitas adalah kewajiban pemegang amanah untuk memberikan pertanggungjawaban, menyajikan, melaporkan, dan mengungkapkan segala aktivitas dan kegiatan yang menjadi tanggungjawabnya kepada pihak pemberi amanah yang memiliki hak dan kewenangan untuk meminta pertanggungjawaban tersebut.

Penggunaan alokasi dana desa yang diterima oleh desa digunakan untuk pembiayaan penyelenggaraan pemerintah desa dan biaya pemberdayaan masyarakat, dimana biaya penyelenggaraan meliputu biaya peralatan kantor dan lingkungan kantor kepala desa, biaya operasional tim pelaksanaan pemerintah, tunjangan dan operasional BPD, tunjangan kepala desa. Sedangkan biaya pemberdayaan masyarakat sendiri meliputi biaya pembangunan sarana dan prasarana desa, PKK, karang taruna, belanja penguatan kelembagaan dan lainnya.

\section{Analisis Akuntabilitas Alokasi Dana Desa (ADD) di Desa Sumber Rejeki Kecamatan Pulau Rimau Kabupaten Banyuasin}

Dari sisi prinsip Akuntabilitas, pelaksanaan Alokasi Dana Desa (ADD), di tempuh melalui sistem pelaporan, yaitu pelaporan pertahun hal ini senada dengan informasi pendapatan yang menyatakan bahwa dalam melaksanakan prinsip akuntabilitas pelaksanaan program Alokasi Dana Desa (ADD), yaitu dengan membuat laporan dan setiap kegiatan ada kuitansi.

Akuntabilitas merupakan suatu kewajiban pemegang amanah untuk memberikan pertanggungjawaban kepada pihak pemberi amanah yang memiliki hak dan kewenangan untuk meminta pertanggungjawaban tersebut, dimana nantinya mendapat keberhasilan dan kegagalan didalam pelaksanaan tugasnya tersebut dalam pencapaian tujuan yang telah ditetapkan. Indikator akuntabilitas terdiri dari perencanaan, pelaksanaan, penatausahaan, pelaporan dan pertanggungjawaban.

Tingkat akuntabilitas dalam implementasi pengelolaan Alokasi Dana Desa di mulai dari perencanaan, pelaksanaan dan pertanggungjawaban. Sebagaimana ketentuan dalam peraturan Desa Sumber Rejeki Kecamatan Pukau Rimau Kabupaten Banyuasin menyebutkan bahwa secara umum pengelolaan Alokasi Dana Desa di Kabupaten Banyuasin harus berpedoman pada prinsip-prinsip sebagai berikut:

1. Seluruh kegiatan yang di danai oleh Alokasi Dana Desa harus direncanakan, dilaksanakan dan dievaluasi secara terbuka dengan melibatkan seluruh unsur masyarakat di desa, serta meningkatkan dan memfungsikan masyarakat yang ada beserta komponen masyarakat yang lain.

2. Pengelolaan keuangan Alokasi Dana Desa merupakan bagian yang tidak terpisah dari pengelolaan keuangan desa maka dari itu Alokasi Dana Desa dilaksanakan dengan menggunakan prinsip hemat, terarah dan terkendali.

Berdasarkan ketentuan di atas maka dapat di jelaskan bahwa Alokasi Dana Desa (ADD) harus dilaksanakan secara terbuka melalui musyawarah desa dan hasilnya dituangkan dalam peraturan.

Alokasi dana desa (ADD) adalah salah satu dana desa yang bersumber dari Anggaran Pendapatan dan Belanja Desa APBDesa, oleh karena itu program 
perencanaan dan kegiatannya disusun melalui Musyawarah perencanaan desa, dengan membahas usulan perencanaan atau program pembangunan desa yang berperinsip pada perencanaan pembangunan masyarakat desa. Prinsip tersebut yang mengharuskan keterlibatan masyarakat dalam pengambilan keputusan dan menentukan pembangunan yang akan dilaksanakan.

\section{Analisis Transparansi Alokasi Dana Desa (ADD) di Desa Sumber Rejeki Kecamatan Pulau Rimau Kabupaten Banyuasin}

Transparan merupakan prinsip yang menjamin akses atau kebebasan bagi setiap orang untuk memperoleh informasi tentang penyelenggaraan pemerintah, yakni informasi tentang kebijakan, proses pembuatan dan pelaksanaannya, serta hasil-hasil yang dicapai.

Transparansi juga merupakan keterbukaan dalam organisasi dan memberikan informasi yang terkait dengan aktivitas pengelolaan sumber daya publik kepada pihak-pihak yang menjadi pemaki kepentingan.

\section{6. $\quad$ Laporan Realisasi di Desa Sumber Rejeki}

Pengelolaan keuangan desa diatur dalam dua rencana kerja, yaitu Rencana Pembangunan Jangka Menengah (RPJM) dan Rencana Kerja Pembangunan (RKP) yang didalamnya direncanakan oleh APBDesa (Anggaran Pendapatan dan Belanja Desa) yang didalamnya berisi informasi program yang akan dikerjakan setiap tahunnya.

Berikut ini adalah laporan realisasi Tahun 2017-2019 di Desa Sumber Rejeki Kecamatan Pulau Rimau Kabupaten Banyuasin.

Tabel Anggaran Pendapatan Dan Belanja Desa Pemerintahan Desa Sumber Rejeki Tahun Anggaran 2017

\begin{tabular}{|c|c|c|c|}
\hline $\begin{array}{c}\text { Kode } \\
\text { Rekening }\end{array}$ & Uraian & Anggaran & $\begin{array}{l}\text { Sumber } \\
\text { Dana }\end{array}$ \\
\hline \multirow[t]{2}{*}{$\begin{array}{l}1 . \\
1.1 . \\
1.1 .3 . \\
1.1 .1 \\
1.2 . \\
1.2 .1 \\
1.2 .3\end{array}$} & $\begin{array}{l}\text { Pendapatan } \\
\text { Pendapatan Asli Desa } \\
\text { Swadaya, Partisipasi dan Gotong Royong } \\
\text { Lain-lain Pendapatan yang Sah } \\
\text { Pendapatan Transfer } \\
\text { Dana Desa } \\
\text { Alokasi Dana Desa }\end{array}$ & $\begin{array}{l}\text { Rp 10.000.000,00 } \\
\operatorname{Rp} 10.000 .000,00 \\
\operatorname{Rp} 0,00 \\
\operatorname{Rp} 1.073 .154 .356,00 \\
\operatorname{Rp} 768.191 .149,00 \\
\operatorname{Rp} 304.963 .207,00\end{array}$ & $\begin{array}{l}\text { PAD } \\
\text { APBN } \\
\text { APBD }\end{array}$ \\
\hline & Jumlah Pendapatan & Rp 1.083.154.356,00 & \\
\hline \multirow[t]{3}{*}{$\begin{array}{l}2 . \\
2.1 . \\
2.1 .1 . \\
2.1 .2 . \\
2.1 .3 .\end{array}$} & $\begin{array}{l}\text { Belanja } \\
\text { Belanja Desa } \\
\text { Belanja Pegawai } \\
\text { Belanja Barang dan Jasa } \\
\text { Belanja Modal }\end{array}$ & $\begin{array}{l}\text { Rp 1.117.178.493,00 } \\
\operatorname{Rp} 189.900 .00,00 \\
\operatorname{Rp} 230.781 .187,00 \\
\operatorname{Rp} 696.497 .306,00\end{array}$ & \\
\hline & Jumlah Belanja & Rp 1.117.178.493,00 & \\
\hline & Surplus / (Defisit) & ( Rp 34.024. 137,00) & \\
\hline \multirow[t]{3}{*}{$\begin{array}{l}3 . \\
3.1 . \\
3.1 .1\end{array}$} & $\begin{array}{l}\text { Pembiayaan } \\
\text { Penerimaan Pembiayaan } \\
\text { Sisa Lebih Perhitungan Anggaran Tahun } \\
\text { Sebelumnya }\end{array}$ & $\begin{array}{l}\text { Rp 34.024.137,00 } \\
\operatorname{Rp} 34.024 .137,00\end{array}$ & \\
\hline & Jumlah Pembiayaan & Rp 34.024.137,00 & \\
\hline & $\begin{array}{l}\text { Sisa Lebih /(Kurang) Perhitungan } \\
\text { Anggaran }\end{array}$ & $\operatorname{Rp} 0,00$ & \\
\hline
\end{tabular}


Berdasarkan tabel diatas anggaran Alokasi Dana Desa (ADD) sudah seharusnya disusun secara partisipatif. Rakyat sebagai hakikat sebagai pemilik anggaran harusnya diajak bermusyawarah darimana dan berapa besar pendapatan desa dan masyarakat juga bisa mengetahui untuk apa saja keuangan desa dibelanjakan. Dengan demikian harapan masyarakat tentang anggaran desa yang digunakan untuk kesejahteraan rakyat dapat benar-benar terwujud.

Tujuan penelitian ini adalah untuk mengetahui tranparansi Alokasi Dana Desa (ADD) di Desa Sumber Rejeki Kecamatan Pulau Rimau Kabupaten Banyuasin, yaitu dari Tahun 2017-2019. Hal ini diharapkan menjadi kajian menarik, karena Alokasi Dana Desa (ADD) sudah berjalan sangat lama sehingga sudah pasti direncanakan lebih baik pengelolaannya dari tahun sebelumnya.

Berikut ini adalah laporan transparansi Alokasi Dana Desa (ADD) tahun 2018 dan tahun 2019 di Desa Sumber Rejeki Kecamatan Pulau Rimau Kabupaten Banyuasin.

Tabel Anggaran Pendapatan Dan Belanja Desa Pemerintahan Desa Sumber Rejeki Tahun Anggaran 2018

\begin{tabular}{|c|c|c|c|}
\hline $\begin{array}{c}\text { Kode } \\
\text { Rekening }\end{array}$ & Uraian & Anggaran & $\begin{array}{l}\text { Sumber } \\
\text { Dana }\end{array}$ \\
\hline \multirow[t]{2}{*}{$\begin{array}{l}\mathbf{1 .} \\
\mathbf{1 . 1 .} \\
1.1 .1 \\
1.1 .3 . \\
\mathbf{1 . 2 .} \\
1.2 .1 . \\
1.2 .3 .\end{array}$} & $\begin{array}{l}\text { Pendapatan } \\
\text { Pendapatan Asli Desa } \\
\text { Hasil Usaha Desa } \\
\text { Swadaya, Partisipasi dan Gotong Royong } \\
\text { Pendapatan Transfer } \\
\text { Dana Desa } \\
\text { Alokasi Dana Desa }\end{array}$ & $\begin{array}{l}\text { Rp } 10.000 .000,00 \\
\operatorname{Rp} 6.000 .000,00 \\
\operatorname{Rp} 4.000 .000,00 \\
\operatorname{Rp} 1.283 .421 .463,00 \\
\text { Rp } 921.720 .426,00 \\
\operatorname{Rp} 361.701 .037,00\end{array}$ & $\begin{array}{l}\text { PAD } \\
\text { APBN } \\
\text { APBD }\end{array}$ \\
\hline & Jumlah Pendapatan & Rp 1.293.421.463,00 & \\
\hline \multirow[t]{3}{*}{$\begin{array}{l}2 . \\
2.1 . \\
2.1 .1 . \\
2.1 .2 . \\
2.1 .3 .\end{array}$} & $\begin{array}{l}\text { Belanja } \\
\text { Belanja Desa } \\
\text { Belanja Pegawai } \\
\text { Belanja Barang dan Jasa } \\
\text { Belanja Modal } \\
\end{array}$ & $\begin{array}{l}\text { Rp 1.330.758.535,00 } \\
\operatorname{Rp} 245.262 .768,00 \\
\operatorname{Rp} 183.530 .805,00 \\
\operatorname{Rp} 901.964 .962,00\end{array}$ & \\
\hline & Jumlah Belanja & Rp 1.330.758.535,00 & \\
\hline & Surplus / (Defisit) & ( Rp 37.337.072,00) & \\
\hline $\begin{array}{l}3 . \\
3.1 . \\
3.1 .1 . \\
3.2 . \\
3.2 .2 .\end{array}$ & $\begin{array}{l}\text { Pembiayaan } \\
\text { Penerimaan Pembiayaan } \\
\text { Sisa Lebih Perhitungan Anggaran Tahun } \\
\text { Sebelumnya } \\
\text { Pengeluaran Pembiayaan } \\
\text { Penyertaan Modal Desa }\end{array}$ & $\begin{array}{l}\operatorname{Rp} 83.202 .498,00 \\
\operatorname{Rp} 83.202 .498,00 \\
\\
\operatorname{Rp} 45.865 .426,00 \\
\operatorname{Rp} 45.865 .426,00\end{array}$ & \\
\hline \multirow{2}{*}{$\begin{array}{l}3.2 . \\
3.2 .2 .\end{array}$} & Jumlah Pembiayaan & Rp 37.337.072,00 & \\
\hline & $\begin{array}{l}\text { Sisa Lebih /(Kurang) Perhitungan } \\
\text { Anggaran }\end{array}$ & $\operatorname{Rp~0,00}$ & \\
\hline
\end{tabular}

Sumber : Laporan Realisasi Tahun 2019 
Tabel Anggaran Pendapatan Dan Belanja Desa Pemerintahan Desa Sumber Rejeki Tahun Anggaran 2019

\begin{tabular}{|c|c|c|c|}
\hline $\begin{array}{c}\text { Kode } \\
\text { Rekening }\end{array}$ & Uraian & Anggaran & $\begin{array}{c}\text { Sumber } \\
\text { Dana }\end{array}$ \\
\hline $\begin{array}{l}4 . \\
4.2 . \\
4.2 .1 \\
4.2 .3 . \\
4.2 .4 . \\
4.3 . \\
4.3 .6 .\end{array}$ & $\begin{array}{l}\text { Pendapatan } \\
\text { Pendapatan Transfer } \\
\text { Dana Desa } \\
\text { Alokasi Dana Desa } \\
\text { Bantuan Keuangan Provinsi } \\
\text { Pendapatan Lain-lain } \\
\text { Bunga Bank }\end{array}$ & $\begin{array}{l}\text { Rp 1.502.288.410,00 } \\
\operatorname{Rp} 1.09 .653 .134,00 \\
\operatorname{Rp} 380.635 .276,00 \\
\operatorname{Rp} 25.000 .000,00 \\
\operatorname{Rp} 0,00 \\
\operatorname{Rp} 0,00\end{array}$ & $\begin{array}{l}\text { APBN } \\
\text { APBD }\end{array}$ \\
\hline & Jumlah Pendapatan & Rp 1.502.288.410,00 & \\
\hline $\begin{array}{l}5 . \\
5.1 . \\
5.1 .1 . \\
5.1 .2 . \\
5.1 .3 . \\
5.1 .4 . \\
5.2 . \\
5.2 .1 . \\
5.2 .2 . \\
5.2 .3 \\
5.2 .4 . \\
5.2 .6 . \\
5.2 .7 . \\
5.3 . \\
5.3 .2 . \\
5.3 .4 . \\
5.3 .5 . \\
5.3 .7 . \\
5.3 .9 .\end{array}$ & $\begin{array}{l}\text { Belanja } \\
\text { Belanja Pegawai } \\
\text { Penghasilan Tetap dan Tunjangan } \\
\text { Kepala Desa } \\
\text { Penghasilan Tetap dan Tunjangan } \\
\text { Perangkat Desa } \\
\text { Jaminan Sosial Kepala Desa dan } \\
\text { Perangkat Desa } \\
\text { Tunjangan BPD } \\
\text { Belanja Barang dan Jasa } \\
\text { Belanja barang perlengkapan } \\
\text { Belanja Jasa Honorarium } \\
\text { Belanja Perjalanan Dinas } \\
\text { Belanja Jasa Sewa } \\
\text { Belanja Pemeliharaan } \\
\text { Belanja Barang dan Jasa yang Diserahkan } \\
\text { Kepada Masyarakat } \\
\text { Belanja Modal } \\
\text { Belanja Modal Pengadaan Peralatan, } \\
\text { Mesin dan Alat Tulis } \\
\text { Belanja Modal Gedung, Bangunan dan } \\
\text { Taman } \\
\text { Belanja Modal Jalan/Prasarana Jalan } \\
\text { Belanja Modal Irigasi/Embung } \\
\text { /Drainase/Air Limbah } \\
\text { Belanja Modal Lain }\end{array}$ & $\begin{array}{l}\text { Rp 275.372.240,00 } \\
\text { Rp 42.000.000,00 } \\
\text { Rp 131.200.000,00 } \\
\text { Rp 11.172.240,00 } \\
\text { Rp 91.000.000,00 } \\
\operatorname{Rp} 302.458 .541,00 \\
\operatorname{Rp} 72.050 .532,00 \\
\operatorname{Rp} 139.800 .000,00 \\
\operatorname{Rp} 38.070 .000,00 \\
\operatorname{Rp} 5.292 .000,00 \\
\operatorname{Rp} 2,199.009,00 \\
\operatorname{Rp} 45.047 .000,00 \\
\text { Rp 850.050.267,40 } \\
\operatorname{Rp} 29.835 .737,00 \\
\operatorname{Rp} 280.150 .230,40 \\
\operatorname{Rp} 399.064 .300,00 \\
\operatorname{Rp} 133.000 .000,00 \\
\operatorname{Rp} 8.000 .000,00\end{array}$ & $\begin{array}{l}\text { ADD } \\
\text { BHPRD }\end{array}$ \\
\hline & $\begin{array}{c}\text { Jumlah Belanja } \\
\text { Surplus / (Defisit) } \\
\end{array}$ & $\begin{array}{l}\operatorname{Rp} 1.427 .881 .048,40 \\
\operatorname{Rp~74.407.361,60} \\
\end{array}$ & \\
\hline $\begin{array}{l}6 . \\
6.1 . \\
6.1 .1 . \\
6.2 . \\
6.2 .2 .\end{array}$ & $\begin{array}{l}\text { Pembiayaan } \\
\text { Penerimaan Pembiayaan } \\
\text { Sisa Lebih Perhitungan Anggaran Tahun } \\
\text { Sebelumnya } \\
\text { Pengeluaran Pembiayaan } \\
\text { Penyertaan Modal Desa }\end{array}$ & $\begin{array}{l}\text { Rp 53.582.824,20 } \\
\text { Rp 53.582.824,20 } \\
\\
\text { Rp 127.990.185,80 } \\
\operatorname{Rp} 127.990 .185,80\end{array}$ & \\
\hline & $\begin{array}{c}\text { Pembiayaan Netto } \\
\text { Sisa Lebih Pembiayaan Anggaran }\end{array}$ & $\begin{array}{l}\operatorname{Rp} 37.337 .072,00 \\
(\operatorname{Rp} 74.407 .361,60)\end{array}$ & \\
\hline
\end{tabular}

Sumber : Laporan Realisasi Tahun 2019

Pemerintah desa setiap tahun wajib menyusn laporan Alokasi Dana Desa (ADD) yang merupakan pembiayaan terhadap program pembangunan tahunan yang diselenggarakan oleh pemerintah desa. Program Alokasi Dana Desa (ADD) di Desa Sumber Rejeki yang menyatakan bahwa proses dari pelaksanaan Alokasi Dana Desa (ADD) pemerintah desa mengundang prangkat desa dan masyarakat guna 
memberikan kesepakatan pada warga untuk mengusulkan program kegiatan tersebu.

Perencanaan adalah awal dari sebuah kegiatan, bila perencanaan dilakukan dengan baik maka akan memberikaan pengaruh yang besar terhadap hasil pelaksanaan kegiatan itu sendiri.

Hasil perencanaan tersebut akan menjadi pedoman penyelenggaraan pemerintah desa dalan pembangunan desa dengan kurun satu tahun. Dengan demikian perencanaan yang disepakati juga harus transparan, dan dapat diketahui oleh masyarakat desa yang nantinya dapat dipertanggungjawabkan.

Pelaksanaan kegiatan yang biayaannya bersumber dari Alokasi Dana Desa (ADD) sepenuhnya dilakukan oleh tim pelaksanaan desa. Dalam pelaksanaan program Alokasi Dana Desa (ADD) dibutuhkan keterbukaan dari tim pelaksana desa kepada seluh masyarakt. Salah satu wujud nyata dari tim pelaksana Desa Sumber Rejeki dalam keterbukaan informasi program Alokasi Dana Desa (ADD) adalah dengan memasang papan informasi yang berisikan tentang besar dana pada tahun berjalan. Keterbukaan informasi merupakan usaha pemerintah desa dalam melaksanakan perinsip transparansi dalam Pengelolaan Alokasi Dana Desa.

Hal tersebut sesuai dengan pendapat dari Bendahara Desa Sumber Rejeki yang menyatakan bahwa dengan adanya keterbukaan dalam mendukung transparansi Alokasi Dana Desa (ADD) maka dibutuhkan papan kegiatan yang sesuai dengan kebutuhan kegiatan sehingga masyarakat desa dapat melihat dan dapat memberikan tanggapan atau saran secara langsung, sehingga aspirasi masyarakat dapat langsung diserap.

\section{E. PEMBAHASAN}

\section{Akuntabilitas Alokasi Dana Desa (ADD) di Desa Sumber Rejeki Kecamatan Pulau Rimau Kabupaten Banyuasin}

Akuntabilitas adalah suatu pertanggungjawabanoleh pihak-pihak yang diberi oleh kepercayaan oleh masyarakat/individu dimana nantinya terdapat keberhasilan atau kegagalan didalam pelaksanaan tugasnya tersebut berkaitan langsung dengan aktvitas birokrasi dalam memberikan pelayanan sebagai prestasi atas hak-hak yang telah dipungut langsung maupun tidak langsung dari masyarakat.

Akuntabilitas memiliki tujuan untuk meningkatkan kinerja pemerintah desa dengan tugas yang dibebankan untuk meningkatkan nilai dan kualitas kegiatan dalam melayani masyarakat.

Penggunaan Alokasi Dana Desa yang diterima oleh Desa digunakan untuk biaya penyelenggaraan pemerintah desa dan biaya pemberdayaan masyarakat. Dimana untuk biaya penyelenggaraan pemerintah meliputi biaya perawatan kantor dan lingkungan kantor kepala desa, biaya operasional tim pelaksana pemerintahan, tunjangan dan operasional BPD, tunjangan kepala desa, honorarium RT/RW, honorarium pengelola keuangan, honorarium PKK, dan lain-lain. Sedangkan untuk biaya pemberdayaan masyarakat sendiri meliputi biaya penggunaan sarana dan prasarana desa, PKK, karang taruna, belanja penguatan kelembagaan dan lainnya.

Akuntabilitas dalam tahap perencanaan, pelaksanaan, penatausahaan serta pelaporan dan pertanggungjawaban pengelolaan Alokasi Dana Desa (ADD) di Desa Sumber Rejeki pada penerapannya sudah berpedoman pada Permendagri Nomor.113 Tahun 2014. Dimana dalam Pengelolaan Alokasi Dana Desa (ADD) sudah melalui tahap perencanaan, pelaksanaan, penatausahaan, serta pelaporan dan pertanggungjawaban. Dalam pertanggungjawaban pemerintah desa terhadap 
Alokasi Dana Desa (ADD) dibuatlah laporan realisasi, laporan realisasi adalah bentuk pertanggungjawaban pemerintah desa terhadap Pengelolaan Alokasi Dana Desa (ADD) yang dilaporkan dua kali dalam setahun atau setiap semester dalam satu tahun.

\section{Transparansi Alokasi Dana Desa (ADD) di Desa Sumber Rejeki Kecamatan Pulau Rimau Kabupaten Banyuasin}

Berdasarkan tujuan yang akan diteliti, yaitu untuk mengetahui akuntabilitas dan transparansi Alokasi Dana Desa (ADD) di Desa Sumber Rejeki Kecamatan Pulau Rimau Kabupaten Banyuasin pada Tahun 2017-2019, sudah diterapkan sesuai sesuai teori dan sudah efektif.

Sehingga penting bagi pemerintah desa untuk merencanakan Pengelolaan Alokasi Dana Desa (ADD) agar kegiatan dalam pembangunan dapat terarah dan terlaksana dengan baik dan dapat dilihat dalam perencanaan program dan kegiatan pemerintah desa yang disusun oleh Kepala desa Sumber Rejeki melalui form Musyawarah Desa (Musdes). Musdes merukapan form pembahasan usulan tentang rencana kegiatan pembangunan ditingkat desa yang mengharuskan keterlibatan masyarakat dalam mengambil keputusan dan memutuskan pembangunan yang akan dilaksanakan di Desa Sumber Rejeki sehingga masyarakat dapat benar-benar merespon aspirasi yang berkembang.

Transparansi berarti pemerintah desa mengelola keuangan dengan keterbukaan, sebab keuangan itu adalah milik rakyat yang harus diketahui oleh masyarakat. Keterbukaan akan meningkatkan kepercayaan dan penghormatan masyarakat kepada pemerintah desa.

Transparansi Pengelolaan Alokasi Dana Desa (ADD) di Desa Sumber Rejeki untuk seluruh penerapannya sudah sesuai pada Permendagri Nomor 113 Tahun 2014, dengan adanya kegiatan pencatatan kas masuk maupun keluar papan pengumuman mengenai kegiatan yang sedang dijalankan, adannya laporan realisasi dan laporan pertanggungjawaban, realisasi pelaksanaan Alokasi Dana Desa (ADD) dapat di informasikan kepada masyarakat secara tertulis dan dengan media informasi yang mudah di akses oleh masyarakat, serta laporan realisasi dan laporan pertanggungjawaban realisasi pelaksanaan Alokasi Dana Desa (ADD) disampaikan kepada Bupati/Walikota melalui camat.

Penelitian ini sejalan dengan penelitian yang dilakukan oleh Nahrudin (2014) menunjukkan bahwa akuntabilitas pengelolaan alokasi dana desa berjalan dengan baik dari keseluruhan dimensi, dan juga transparansi pengelolaan alokasi dana desa sudah berjalan dengan baik, hal ini dapat dilihat dari adanya informasi yang mudah di akses serta komunikasi yang baik oleh perangkat desa.

Penelitian ini juga sejalan dengan penelitian yang dilakukan oleh Widiyanti (2017) menunjukanbahwa secara garis besar pengelolaan alokasi dana desa di Desa Sumberejo sudah akuntabel dan trasparan pada tahap penatausahaan, pelaporan, dan pertanggungjawaban.

Penelitian lain juga dilakukan oleh Widiyanti (2017) menunjukan bahwa Akuntabilitas dan Transparasi kedua Desa terhadap masyarakat sudahn terlaksana dengan baik. Sehingga dapat disimpulkan bahwa Desa Sumberejo dan Desa Kandung sudah akuntabel dan kedua desa tersebut cukup transparan.

\section{F. KESIMPULAN DAN SARAN}

1) Kesimpulan 
Berdasarkan hasil penelitian yang dilakukan mengenai Akuntabilitas dan Transparansi Pengelolaan Alokasi Dana Desa di Desa Sumber Rejeki Kecamatan Pulau Rimau Kabupaten Banyuasin periode 2017-1019, maka dapat disimpulkan bahwa:

1. Tahap perencanaan Alokasi Dana Desa di Desa Sumber Rejeki sudah menerapkan tranparansi dan partisipasi. Hal ini dibuktikan dengan adanya masyarakat yang antusias menghadiri forum musyawarah desa. Dalam musyawarah desa pemerintah desa juga sangat terbuka dalam menerima usulan dari masyarakat.

2. Tahap pertanggungjawaban Alokasi Dana Desa sudah menerapkan akuntabilitas dengan baik secara teknis maupun administrasi namun harus tetap mendapat bimbingan dari pemerintah Kecamatan.

\section{2) Saran}

Berdasarkan hasil penelitian dan kesimpulan yang telah diuraikan, maka peneliti dapat memberikan saran sebagai berikut:

1. Bagi pemerintah desa perlu meningkatkan keterampilan teknik penggunaan aplikasi sistem keuangan desa untuk meningkatkan kinerja aparat desa, selain itu juga perlunya dukungan aparat desa agar lebih berpartisipasi dalam dokumentasi agar hasil penelitian dapat menggambarkan kondisi secara utuh.

2. Bagi peneliti selanjutnya yang akan melakukan penelitian dengan topik yang sama, maka hendaknya menggunakan variable-variabel yang berbeda memperluas bidang kajian dan periode penelitian yang terbaru dan actual, sehingga hasil penelitiannya akan lebih sesuai pada saat penelitian.

\section{DAFTAR PUSTAKA}

Alfasadun, d. (2018). Transparasi dan Pengelolaan Dana Desa. Prosiding SENDI_U 2018, 684.

Hermawan, A. d. (2017). Penelitian Bisnis Pendekatan Kuantitatif. Depok: Kencana Prenamedia Group.

Kadek Sinarwati, d. (2017). Akuntabilitas Dan Transparasi Pengelolaan Alokasi Dana Desa (ADD) di Desa Bubunan Kecamatan Seririt Kabupaten Buleleng. Universitas Pendidikan Ganesha Jurusan Akuntansi Program S1, 8(2), 2.

Mahmudi. (2011). Akuntansi Sektor Publik. Yogyakarta: UII Press Yogyakarta.

Nahruddin, Z. (2014). Akuntabilitas dan Transparasi Pengelolaan Dana Alokasi Desa di Desa Pao-Pao Kecamatan Tanete Rilau Kabupaten Barru. Universitas Muhammadiyah Makasar, 194.

Noor, J. (2015). Metodologi Peneitian. Jakarta: Kencana Prenadamedia Group.

Peraturan Bupati No 12 Tahun 2015. Tentang Alokasi Dana Desa

Permendagri Nomor. 113. 2014. Tentang Pengelolaan Keuangan Desa.

Rangga, I., \& Setyadi, E. (2019). Panduan Penggunaan Dan Pengelolaan Dana Desa. Jakarta: PT Grasindo. 
Sugiyono. (2018). Metode Penelitian Bisnis. Bandung: Alfabeta.

Sujarweni, W. (2015). Akuntansi Desa. Yogyakarta: Pustaka Baru Press.

Sujarweni, W. (2019). Metodologi Penelitian Bisnis dan Ekonomi. Yogyakarta: Pustaka Baru Press.

Undang-Undang Nomor. 6 Tahun 2014. Tentang Desa.

Undang-Undang Desa No. 6 Tahun 2014 Pasal 72 Ayat 3. Tentang Pendapatan Dana Desa

Undang-Undang No. 6 Tahun 2014 Pasal 66. Tentang Penghasilan Kepala Desa dan Perangkat Desa

Undang-Undang No. 6 Tahun 2014 Pasa 72. Tentang Wewenang Kepala Desa

Undang-Undang No. 6 Tahun 2014 Pasal 39. Tentang Masa Jabatan Kepala Desa

Undang-Undang No. 6 Tahun 2014 Pasal 55. Tentang Badan Permusyawaratan Desa

Undang-Undang No. 6 Tahun 2014 Pasal 72 Ayat 1. Tentang Sumber Pendapatan Desa. 